\title{
Electron Capture in Spin-Trap Capped Peptides. An Experimental Example of Ergodic Dissociation in Peptide Cation-Radicals
}

\author{
Jace W. Jones, Tomikazu Sasaki, David R. Goodlett, \\ and František Tureček \\ Department of Chemistry and Medicinal Chemistry, University of Washington, Seattle, Washington, USA
}

Electron capture dissociation was studied with tetradecapeptides and pentadecapeptides that were capped at $\mathrm{N}$-termini with a 2-(4'-carboxypyrid-2'-yl)-4-carboxamide group (pepy), e.g., pepy-AEQLLQEEQLLQEL-NH ${ }_{2}$, pepy-AQEFGEQGQKALKQL-NH ${ }_{2}$, and pepy-AQEGSEQAQKFFKQL- $\mathrm{NH}_{2}$. Doubly and triply protonated peptide cations underwent efficient electron capture in the ion-cyclotron resonance cell to yield charge-reduced species. However, the electron capture was not accompanied by backbone dissociations. When the peptide ions were preheated by absorption of infrared photons close to the dissociation threshold, subsequent electron capture triggered ion dissociations near the remote $C$-terminus forming mainly $\left(\mathbf{b}_{11-14}\right.$ $+1)^{+\cdot}$ fragment ions that were analogous to those produced by infrared multiphoton dissociation alone. Ab initio calculations indicated that the $\mathrm{N}-1$ and $\mathrm{N}-1^{\prime}$ positions in the pepy moiety had topical gas-phase basicities $\left(\mathrm{GB}=923 \mathrm{~kJ} \mathrm{~mol}^{-1}\right)$ that were greater than those of backbone amide groups. Hence, pepy was a likely protonation site in the doubly and triply charged ions. Electron capture in the protonated pepy moiety produced the ground electronic state of the charge-reduced cation-radical with a topical recombination energy, $\mathrm{RE}=5.43-5.46$ $\mathrm{eV}$, which was greater than that of protonated peptide residues. The hydrogen atom in the charge-reduced pepy moiety was bound by $>160 \mathrm{~kJ} \mathrm{~mol}^{-1}$, which exceeded the hydrogen atom affinity of the backbone amide groups (21-41 $\mathrm{kJ} \mathrm{mol}^{-1}$ ). Thus, the pepy moiety functioned as a stable electron and hydrogen atom trap that did not trigger radical-type dissociations in the peptide backbone that are typical of ECD. Instead, the internal energy gained by electron capture was redistributed over the peptide moiety, and when combined with additional IR excitation, induced proton-driven ion dissociations which occurred at sites that were remote from the site of electron capture. This example of a spin-remote fragmentation provided the first clear-cut experimental example of an ergodic dissociation upon ECD. (J Am Soc Mass Spectrom 2007, 18, 432-444) () 2007 American Society for Mass Spectrometry

$\mathrm{D}$ issociations of peptide cations have been of much interest owing to their analytical utility for peptide identification and sequencing to be used in proteomics. Under low-energy excitation by collisions or infrared multi-photon absorption, peptide cations undergo mainly $\mathrm{C}(\mathrm{O})-\mathrm{N}$ bond dissociations producing series of $\mathrm{N}$-terminal (b ions) and C-terminal (y ions) fragments. The current mechanisms of peptide ion dissociations consider multiple proton transfers in the peptide ion reactant, as expressed by the so-called "mobile proton" model [1]. Mechanistic details of peptide cation dissociations and the product ion structures have been elucidated by quantum chemical calculations [2-4] and appear to provide a coherent model of the peptide gas-phase ion chemistry [5]. Inherent to the

Published online November 16, 2006

Address reprint requests to Dr. F. Tureček, Department of Chemistry, University of Washington, Bagley Hall, Box 351700, Seattle, WA 98195-1700,

USA. E-mail: turecek@chem.washington.edu mechanistic model of peptide ion fragmentations is the concept of efficient internal vibrational energy redistribution (IVR) in the dissociating peptide ion [6], so that the dissociation can be treated as an ergodic process by appropriate kinetic schemes, such as the RiceRamsperger-Kassel-Marcus [7] or transition-state theories [8]. The concept of IVR has received experimental support by time-resolved photodissociation studies [9], and is consistent with the mode of excitation upon collisional activation at low kinetic energies $(<100 \mathrm{eV})$ or upon absorption of infrared photons [10].

The current understanding is less definite concerning the dissociations of peptide cation-radicals produced by electron capture or transfer [11]. In electron capture (ECD) and electron-transfer dissociations (ETD) [12], multiply charged peptide cations are partially discharged by receiving one or more electrons and thus are converted from even-electron, closed-electronic shell species to cation-radicals. Peptide cation-radicals are reactive and undergo a variety of dissociations on 
the time scale of the experimental measurements in ion-cyclotron resonance, which is typically $>100 \mathrm{~ms}$. The bond dissociations observed upon ECD mainly concern the peptide $\mathrm{N}-\mathrm{C}_{\alpha}$ bonds [13], but also include various $\mathrm{N}-\mathrm{H}, \mathrm{N}-\mathrm{C}$, and $\mathrm{C}-\mathrm{C}$ bonds in the amino acid side chains [14].

Multiply protonated peptide cations have substantial recombination energies that are estimated at $5.5 \mathrm{eV}$ [15] based on the intrinsic recombination energies of the charge-carrying groups, such as lysine ammonium [16], arginine guanidinium [17], histidine imidazolium [18], and through-space Coulomb effects [15]. The latter act pair-wise, and the electron stabilization energies per positive-charge-electron interaction (in $\mathrm{eV}$ ) depend on the charge distance $r_{\mathrm{ij}}$ (in angstroms) according to eq 1 , where the dielectric separating the charges is presumed to be vacuum:

$$
E_{\text {coulomb }}(\mathrm{eV})=\frac{-14.3996}{r_{i j}}
$$

The substantial electron recombination energies cause the energy gained upon electron capture or transfer to exceed the typical bond dissociation energies in peptide ions. This raises the question of whether the electronic energy is redistributed by internal conversion among the vibrational degrees of freedom before bond dissociation. It was postulated early on that ECD was a nonergodic process [11], because the vibrational excitation gained upon electron capture was deemed insufficient to cause dissociation if the energy was randomized among the many degrees of freedom in the ion. However, ab initio theoretical analysis of bond dissociation and transition-state energies in charge-reduced peptides and a number of simple peptide model systems revealed those energies to be extremely low [16, 19-21]. This suggested that dissociation can be expected to be fast even in fully thermalized charge-reduced ions, and thus it was concluded that there was no need to invoke nonergodic behavior [16, 19]. Recently, excited electronic states in charge-reduced peptide cationradicals and their simple models have been analyzed $[22,23]$, and another mechanism, termed "amide superbase", has been suggested to account for ECD and ETD occurring at peptide bonds that are remote from the charge-carrying group [22]. However, in spite of the continuing debate $[16,19,24]$, experimental evidence supporting or excluding nonergodic dynamic effects in ECD has been absent. We now report an experimental ECD study of peptide conjugates that clearly shows that internal energy gained upon electron capture is randomized in these peptide ions before dissociation. To the best of our knowledge, this is the first direct evidence of IVR following electron capture in a multiply charged peptide.

\section{Experimental}

The peptide conjugates used in this study, pepy-AEQLLQEEQLLQEL-NH2 (P1) pepy-AQEFGEQGQKALKQL-NH $_{2}\left(\mathbf{P}_{2}\right)$, pepy-AQEGSEQAQKFFKQL-NH $\left(\mathbf{P}_{3}\right)$ were synthesized and characterized previously [25]. The corresponding peptides, AEQLLQEEQLLQEL $\left(\mathbf{p}_{1}\right)$, AQEFGEQGQKALKQL $\left(\mathbf{p}_{2}\right)$, and AQEGSEQAQKFFKQL $\left(\mathbf{p}_{3}\right)$, were synthesized as free acids using an automatic peptide synthesizer (ResPep MicroScale, Intavis AG, Köln, Germany) according to the F-moc synthesis strategy. The peptide identity and amino acid sequence were confirmed by MS/MS collision-induced dissociation and infrared multiphoton dissociation, as described below. Peptide solutions in 50:50 methanolwater at 10 to $50 \mu \mathrm{M}$ concentrations were electrosprayed to form mainly doubly and triply protonated cations that were selected by $\mathrm{m} / \mathrm{z}$ ratios and used for collision-induced dissociation (CID), infrared multiphoton dissociation (IRMPD), and electron capture dissociation (ECD) studies.

CID spectra were obtained on an Esquire LC ion trap mass spectrometer (Bruker Daltonics, Billerica, MA) equipped with an electrospray ion source. The sample solution was directly infused into the ion source at a flow rate of $1.5 \mu \mathrm{L} / \mathrm{min}$. The parameters for the ion source and mass spectrometer were as follows: capillary voltage, $-4000 \mathrm{~V}$; end plate, $500 \mathrm{~V}$; capillary offset, $70 \mathrm{~V}$; skimmer 1 set at $30 \mathrm{~V}$; skimmer 2 set at $4 \mathrm{~V}$; octopole, 3 $\mathrm{V}$, trap drive, 55 to $80 \mathrm{~V}$; ion charge control on with target 25,000 ions; nebulizing gas $\left(\mathrm{N}_{2}\right), 9.0$ psi; drying gas $\left(\mathrm{N}_{2}\right), 3 \mathrm{~L} / \mathrm{min}$; drying temperature, $250{ }^{\circ} \mathrm{C}$. MS /MS spectra were collected with an isolation width of $4 \mathrm{mu}$ and the fragmentation amplitude set to $1 \mathrm{~V}$. The mass accuracy of the data were $\pm 0.3 \mu$.

ECD and IRMPD spectra were obtained on an actively shielded 4.7-T Fourier transform ion-cyclotron resonance (FT-ICR) mass spectrometer (APEX-III, Bruker Daltonics) upgraded with a mass-selective quadrupole $(\mathrm{Q})$ front-end. Positive ions were produced by direct infusion into an external Apollo electrospray ion source (Bruker Daltonics) at a flow rate of 1.5 $\mu \mathrm{L} / \mathrm{min}$ with the assistance of $\mathrm{N}_{2}$ nebulizing gas $(8.0$ psi). The ESI source was operated under the following conditions: cylinder, $0 \mathrm{~V}$; capillary, $-4490 \mathrm{~V}$; end plate, $-4080 \mathrm{~V}$; cap exit, $90 \mathrm{~V}$; skimmer 1, $20 \mathrm{~V}$; skimmer 2, 5.8 $\mathrm{V}$; offset, $3 \mathrm{~V}$; trap and extract, $7.4 \mathrm{~V}$ and $-6.7 \mathrm{~V}$, respectively; drying gas $\left(\mathrm{N}_{2}\right), 3 \mathrm{~L} / \mathrm{min}$; drying temperature, $150{ }^{\circ} \mathrm{C}$. The generated ions were accumulated in the first hexapole for $0.1 \mathrm{~s}$, transferred into the massselective quadrupole, and the mass-selected ions were accumulated for 1 to $3 \mathrm{~s}$ in the second hexapole. Ion optics further transferred ions into an Infinity ICR cell [26] where they were trapped by gating the trapping potentials. All spectra were acquired using XMASS software (Bruker Daltonics) with $512 \mathrm{k}$ data points over a $\mathrm{m} / \mathrm{z}$ range of 250 to 2000 and summed over 25 to 50 scans. ECD experiments were performed with an indirectly heated cathode (Heatwave, Crescent Valley, BC, 
Canada) operated at $1.7 \mathrm{~A}$ of heater current. During the ECD event, ions were selected by the external quadrupole mass filter then transferred into the ICR cell where they were irradiated by a pulse of 3 to $5 \mathrm{eV}$ electrons for a duration of 50 to $300 \mathrm{~ms}$. The electron energy was optimized for maximum conversion. IRMPD experiments were performed using a $25-\mathrm{W}$ infrared $\mathrm{CO}_{2}$ laser (Synrad, model 48-2-2, Mukilteo, WA). During the IRMPD event, ions were selected by the external quadrupole mass filter then transferred into the ICR cell where they were irradiated by a pulse of 10 to $35 \%$ laser power for a duration of 10 to $300 \mathrm{~ms}$. The $\mathrm{m} / \mathrm{z}$ values from both instruments are reported as rounded-off integer numbers. Accurate mass measurements were also carried out on the Bruker Apex FT-MS instrument to verify the elemental composition of the ions under study. The measured accurate $\mathrm{m} / \mathrm{z}$ values were within 1 millimass unit of the theoretical ones.

The neutralization-reionization mass spectrum of protonated 2,2'-bipyridine was measured on a tandem quadrupole acceleration-deceleration instrument described previously [27]. 2,2'-Bipyridine was electrosprayed from $80 \mu \mathrm{M}$ solution in methanol, the (bpy + $\mathrm{H})^{+}$ions at $\mathrm{m} / \mathrm{z} 157$ ions were transmitted to the vacuum system by a special interface [28], accelerated to $8250 \mathrm{eV}$ kinetic energy, and discharged by glancing collisions with dimethyl disulfide as electron donor that was admitted to the collision chamber at pressures to allow $70 \%$ transmittance of the ion beam $(83 \%$ single collisions). The residual ions were stopped by a $+250 \mathrm{~V}$ potential and the radicals were allowed to drift $60 \mathrm{~cm}$ to a down-beam collision chamber where a fraction was nonselectively reionized to cations by collisions with $\mathrm{O}_{2}$ at $70 \%$ beam transmittance. The lifetime of the radical intermediates was $6 \mu \mathrm{s}$ [29]. The resulting ions were decelerated to $75 \mathrm{eV}$ kinetic energy, energy filtered, and mass-analyzed by a quadrupole mass spectrometer that was floated at $72 \mathrm{~V}$ and operated at unit mass resolution [30]. The reported ${ }^{+} \mathrm{NR}^{+}$mass spectrum is weighted average of 50 repetitive scans obtained at a scan rate of 200 points/mass unit.

\section{Calculations}

Standard ab initio calculations were performed using the Gaussian 03 suite of programs [31]. Optimized geometries were obtained by density functional theory calculations using Becke's hybrid functional (B3LYP) [32] and the 6-31 $+\mathrm{G}(\mathrm{d}, \mathrm{p})$ basis set. Complete optimized structures of all local minima and transition states can be obtained from the corresponding author (FT) upon request. Spin unrestricted calculations were performed for all open-shell systems. Stationary points were characterized by harmonic frequency calculations with B3LYP/6-31 + G(d,p) as local minima (all real frequencies) and first-order saddle points (one imaginary frequency). The calculated frequencies were scaled with 0.963 and used to obtain zero-point energy corrections, enthalpies, and entropies. The rigid-rotor har- monic oscillator (RRHO) model was used in thermochemical calculations except for low-frequency modes, where the vibrational enthalpy terms that exceeded 0.5 RT were replaced by free internal rotation terms equal to $0.5 \mathrm{RT}$. It has been shown previously that enthalpies and entropies based on the RRHO and free rotation approximations bracket the more accurate values calculated with the hindered internal rotor model [33], and the small differences cancel out in calculations of relative enthalpies and entropies. Improved energies were obtained by single-point B3LYP and Møller-Plesset calculations [34] with valence-electron excitations (MP2[frozen core]) and the larger 6-311 ++ G(3df,2p) split-valence, triple- $\zeta$ basis set furnished with polarization and diffuse functions. The B3LYP and MP2 energies calculated with the large basis set were combined according to the B3-MP2 scheme, as described previously [35]. This correction has been shown by us [36] and others [37] to provide accurate relative energies that are comparable to those from correlated ab initio calculations.

\section{Results}

Pepy-Peptide Conjugates $P_{1}, P_{2}$, and $P_{3}$

Electrospray ionization of pepy-AEQLLQEEQLLQEL$\mathrm{NH}_{2}\left(\mathbf{P}_{1}\right)$ produced mainly doubly-protonated ions denoted as $\left(\mathbf{P}_{1}+2 \mathrm{H}\right)^{2+}$ at $m / z$ 955.0, accompanied by $\left(\mathbf{P}_{1}\right.$ $+\mathrm{H}+\mathrm{Na})^{2+}$ at $m / z 966.0$, and a fragment $\left(\mathbf{P}_{1}+2 \mathrm{H}-\right.$ $\left.\mathrm{NH}_{3}\right)^{2+}$ at $\mathrm{m} / \mathrm{z}$ 946.5. The identity of these ions was ascertained by accurate mass measurements on the ICR-FT-MS instrument. CID of mass-selected $\left(\mathbf{P}_{\mathbf{1}}+\right.$ $2 \mathrm{H})^{2+}$ ions in the quadrupole ion trap formed a series of singly charged $\mathbf{b}$ and $\mathbf{y}$ ions that provided practically complete amino acid sequence coverage of the peptide (Figure 1a). The sequence ion assignment that is used hereinafter counts the pepy moiety as a pseudoamino acid residue; for example, the $\mathbf{b}_{3}$ ion in Figure 1a comprises pepy-AE and likewise for the other $\mathbf{b}$ ions. Also observed were doubly charged fragments of $\left(\mathbf{P}_{1}+\right.$ $\left.2 \mathrm{H}-\mathrm{NH}_{3}\right)^{2+}$ at $\mathrm{m} / z 946.5$ and $\mathbf{b}_{14}^{2+}$ at $\mathrm{m} / \mathrm{z}$ 891.0. Noteworthy is the dominant $\mathbf{b}$-ion series, $\mathbf{b}_{3}-\mathbf{b}_{14}$, which indicates that one of the ionizing protons is located at or near the pepy-capped $\mathrm{N}$-terminus. The second proton is probably close to the C-terminus, as judged from both the presence of the dominant $\mathbf{b}_{14}^{2+}$ fragment and absence of other doubly charged sequence fragments. Similar results were obtained by IRMPD in the ICR cell of mass selected $\left(\mathbf{P}_{1}+2 \mathrm{H}\right)^{2+}$ (Figure $\left.1 \mathrm{~b}\right)$, which also showed dominant $\mathbf{b}$-type ions.

ECD of mass-selected $\left(\mathbf{P}_{\mathbf{1}}+2 \mathrm{H}\right)^{2+}$ showed depletion of the doubly charged ion population and formation of charge-reduced $\left(\mathbf{P}_{\mathbf{1}}+2 \mathrm{H}\right)^{+\cdot}$ ions at $m / z 1910$ and their dissociation products $\left(\mathbf{P}_{\mathbf{1}}+2 \mathrm{H}-\mathrm{NH}_{3}\right)^{+\cdot}$ at $m / z 1893$ (Figure 2). The $\left(\mathbf{P}_{\mathbf{1}}+2 \mathrm{H}\right)^{2+}$ signal depletion was measured as a function of the electron irradiation time and found to follow first-order kinetics (Figure 2, inset). At $250 \mathrm{~ms}$ irradiation time, $>50 \%$ of $\left(\mathbf{P}_{\mathbf{1}}+2 \mathrm{H}\right)^{2+}$ was 


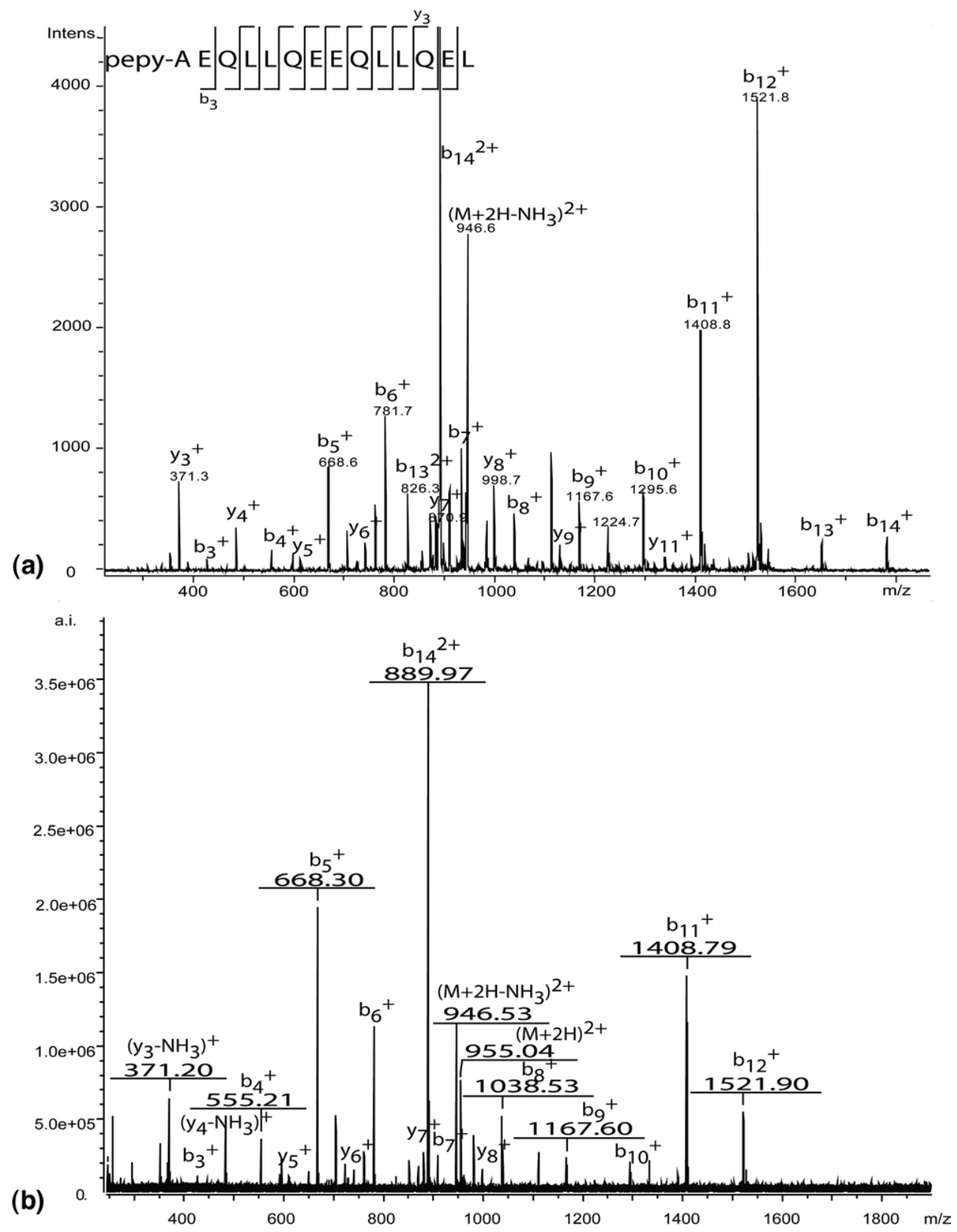

Figure 1. (a) Collision-induced dissociation mass spectrum of $\left(\mathbf{P}_{\mathbf{1}}+2 \mathrm{H}\right)^{2+}$ measured in a quadrupole ion trap. (b) Infrared multiphoton dissociation mass spectrum of $\left(\mathbf{P}_{\mathbf{1}}+2 \mathrm{H}\right)^{2+}$ measured by FT-MS. Irradiation time was $150 \mathrm{~ms}$ at 35\% laser power.

converted to singly charged $\left(\mathbf{P}_{1}+2 \mathrm{H}\right)^{+\cdot}$ and $\left(\mathbf{P}_{1}+2 \mathrm{H}\right.$ $\left.-\mathrm{NH}_{3}\right)^{+\cdot}$ ions. However, no ECD sequence fragments of the $\mathbf{c}$ or $\mathbf{z}$ type were observed.

Very similar results were obtained for ECD of doubly and triply charged pepy-AQEFGEQGQKALKQL$\mathrm{NH}_{2}$, denoted as $\left(\mathbf{P}_{\mathbf{2}}+2 \mathrm{H}\right)^{2+}$ and $\left(\mathbf{P}_{\mathbf{2}}+3 \mathrm{H}\right)^{3+}$, respectively, and pepy-AQEGSEQAQKFFKQL-NH ${ }_{2}$, denoted as $\left(\mathbf{P}_{3}+2 \mathrm{H}\right)^{2+}$ and $\left(\mathbf{P}_{3}+3 \mathrm{H}\right)^{3+}$, respectively, Electron capture in these mass-selected ions resulted in efficient charge reduction at up to $50 \%$ conversion to the lower charge states, but no dissociation. Again, charge reduction in $\left(\mathbf{P}_{2}+2 \mathrm{H}\right)^{2+}$ followed first-order kinetics when measured as a function of the electron irradiation time.
The effects on fragmentation of peptide internal energy were investigated in a series of tandem excitation experiments. In the first of these, mass-selected $\left(\mathbf{P}_{\mathbf{1}}\right.$ $+2 \mathrm{H})^{2+}$ ions were stored and irradiated with infrared photons to the brink of dissociation. This tickling was accomplished by monitoring the formation of the $\left(\mathbf{P}_{\mathbf{1}}+\right.$ $\left.2 \mathrm{H}-\mathrm{NH}_{3}\right)^{2+}$ fragment ions that represent the products of the lowest-energy dissociation, and adjusting the irradiation pulse width to achieve $<20 \%$ ion dissociation by loss of ammonia. Subsequently, the ions were irradiated with a $300 \mathrm{~ms}$ pulse of $4.5 \mathrm{eV}$ electrons and the resulting IRMPD/ECD spectra were recorded. These showed substantial dissociation of $\left(\mathbf{P}_{\mathbf{1}}+2 \mathrm{H}\right)^{+\cdot}$ by 


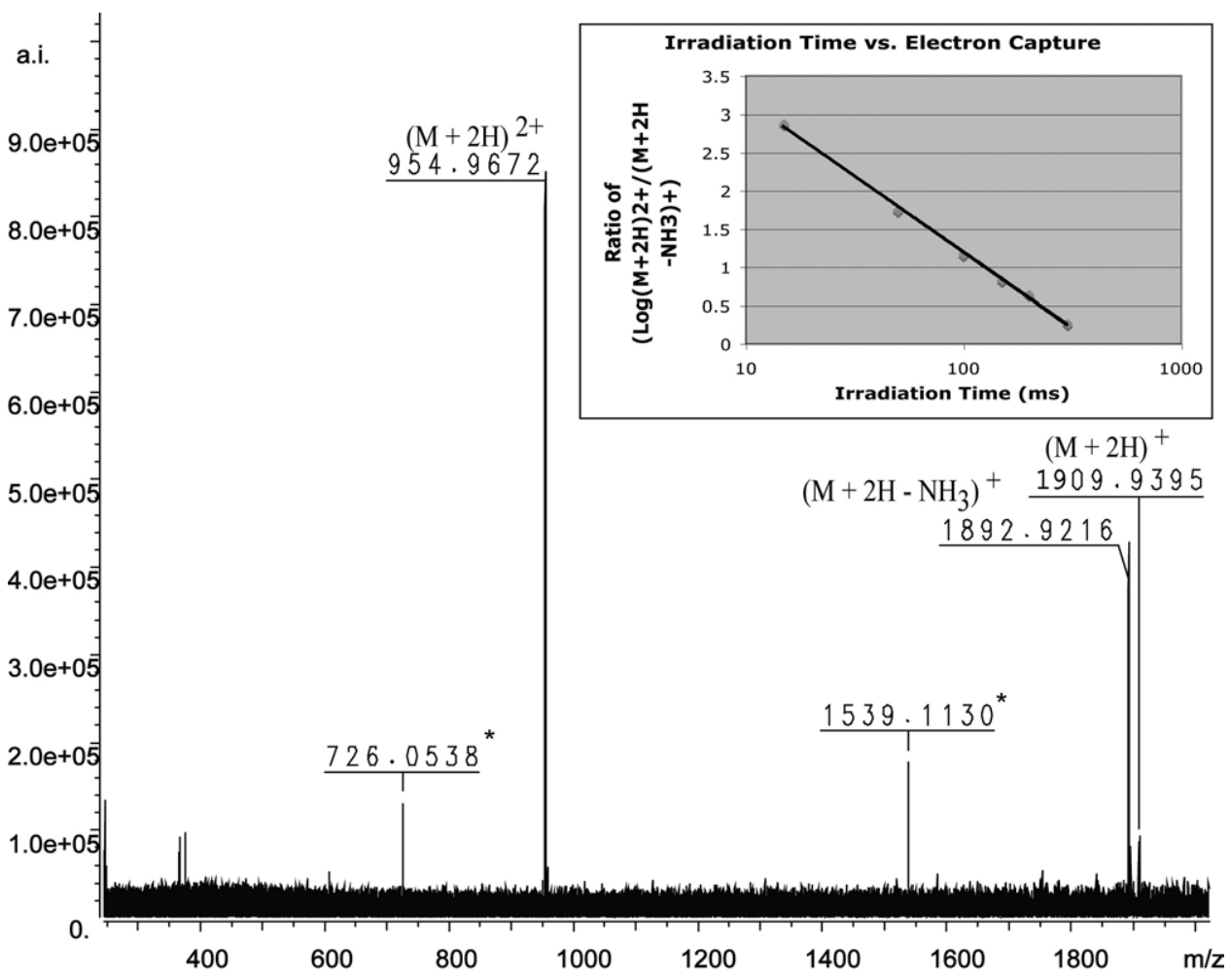

Figure 2. Electron-capture dissociation mass spectrum of $\left(\mathbf{P}_{\mathbf{1}}+2 \mathrm{H}\right)^{2+}$. Electron irradiation time was $150 \mathrm{~ms}$ with an electron beam energy of $4.5 \mathrm{eV}$. Peaks labeled with asterisks were assigned and considered artifacts. Inset shows the $\log \left\{\left[\mathbf{P}_{\mathbf{1}}+2 \mathrm{H}\right]^{2+} /\left[\mathbf{P}_{\mathbf{1}}+2 \mathrm{H}-\mathrm{NH}_{3}\right]^{+\cdot}\right\}$ as a function of electron irradiation time.

loss of ammonia and peptide backbone fragmentations (Figure 3a). However, the backbone fragments observed belonged to the high $\left(\mathbf{b}_{\mathrm{n}}+1\right)$ series, e.g., $\left(\mathbf{b}_{14}+1\right),\left(\mathbf{b}_{12}\right.$ $+1)$, and $\left(\mathbf{b}_{11}+1\right)$ at $m / z$ 1780, 1523, and 1410, respectively. A few ECD-type fragment ions were also observed, e.g., $\left(\mathbf{z}_{13}+1\right)$ at $m / z 1595$ and $\left(\mathbf{z}_{10}+1\right)$ at $m / z$ 1226 (Figure $3 \mathrm{a}$ ). The formation of the rather unusual $b_{\mathrm{n}}$ +1 ions is readily accounted for by ion-driven dissociations at residues close to the C-terminus, whereby the 1 Da mass increment is due to the other proton that has been neutralized by electron capture (Scheme 1).

A reverse irradiation sequence was also investigated whereby mass-selected $\left(\mathbf{P}_{\mathbf{1}}+2 \mathrm{H}\right)^{2+}$ were first irradiated with electrons and the products of electron capture were subjected to IRMPD without mass selection. IRMPD of charge-reduced ions at $15 \mathrm{~ms}$ laser pulse time caused elimination of ammonia from $\left(\mathbf{P}_{\mathbf{1}}+2 \mathrm{H}\right)^{+\cdot}$ as the only significant dissociation. Low-intensity $\left(\mathbf{b}_{14}+1\right)$ and $\left(\mathbf{b}_{12}+1\right)$ backbone fragments were also observed upon ECD/IRMPD (Figure 3b).

\section{Peptides $p_{1}, p_{2}$, and $p_{3}$ Lacking Pepy}

In light of the unusual behavior of $\left(\mathbf{P}_{\mathbf{1}}+2 \mathrm{H}\right)^{2+},\left(\mathbf{P}_{\mathbf{2}}+\right.$ $2 \mathrm{H})^{2+}$ and $\left(\mathbf{P}_{3}+2 \mathrm{H}\right)^{2+}$ upon ECD, we studied the fragmentations of peptide ions that lacked the pepy group. Upon CID and IRMPD, the doubly charged ( $\mathbf{p}_{\mathbf{1}}$ $+2 \mathrm{H})^{2+}$ ion from peptide AEQLLQEEQLLQEL, $\left(\mathbf{p}_{1}\right)$ showed extensive sequence coverage through series of complementary $\mathbf{b}_{3}-\mathbf{b}_{12}$ and $\mathbf{y}_{2}-\mathbf{y}_{11}$ fragment ions (Figure $4 \mathrm{a}$ and $\mathrm{b})$. ECD of $\left(\mathrm{p}_{1}+2 \mathrm{H}\right)^{2+}$ also resulted in dissociation forming the $c_{9}, c_{11}$, and $c_{12}$ fragments, together with products of side-chain cleavages and losses of $\mathrm{C}_{2} \mathrm{H}_{5} \mathrm{O}$ and $\mathrm{C}_{3} \mathrm{H}_{5} \mathrm{NO}$ (Figure $4 \mathrm{c}$ ). IRMPD following ECD of $\left(\mathrm{p}_{1}+2 \mathrm{H}\right)^{2+}$ was also performed but did not result in enhanced dissociation (Figure $4 \mathrm{~d}$ ). Noteworthy is the much lower conversion to lower charge states of $\left(\mathbf{p}_{\mathbf{1}}+\right.$ $2 \mathrm{H})^{2+}$ compared with that of $\left(\mathbf{P}_{\mathbf{1}}+2 \mathrm{H}\right)^{2+}$ (Figure 2$)$.

Similar results were obtained for the $\left(\mathrm{p}_{2}+2 \mathrm{H}\right)^{2+}$ ions from peptide AQEFGEQGQKALKQL $\left(\mathbf{p}_{2}\right)$. Both CID (Figure 5a) and IRMPD (Figure 5b) showed extensive sequence coverage. ECD (Figure 5c) and ECD/ IRMPD (Figure 5d) showed regular backbone fragments of the $\mathbf{c}$ and $\mathbf{z}$ series, e.g., $\left(\mathbf{z}_{13}+1\right), \mathbf{z}_{12},\left(\mathbf{z}_{10}+1\right)$, $\left(\mathbf{z}_{9}+1\right), \mathbf{c}_{14}, \mathbf{c}_{12},\left(\mathbf{c}_{11}-1\right)$, and $\mathbf{c}_{10}$. Again, ECD of the $\left(\mathbf{p}_{2}\right.$ $+2 \mathrm{H})^{2+}$ ions was substantially less efficient than for their pepy conjugates $\left(\mathbf{P}_{2}+2 \mathrm{H}\right)^{2+}$.

\section{Discussion}

The ECD and combined ECD/IRMPD and IRMPD/ ECD spectra show that the pepy group has a large effect on both electron capture and the following fragmentations. To recapitulate, peptides $\mathbf{p}_{\mathbf{1}}-\mathbf{p}_{3}$ that lack the pepy group show more or less regular ECD behavior resulting in radical-induced side-chain losses and backbone fragments of the $\mathbf{c}$ and $\mathbf{z}$ series, combined with hydrogen transfers forming the $(\mathbf{c}-1)$ and $(\mathbf{z}+1)$ fragment 
(a)
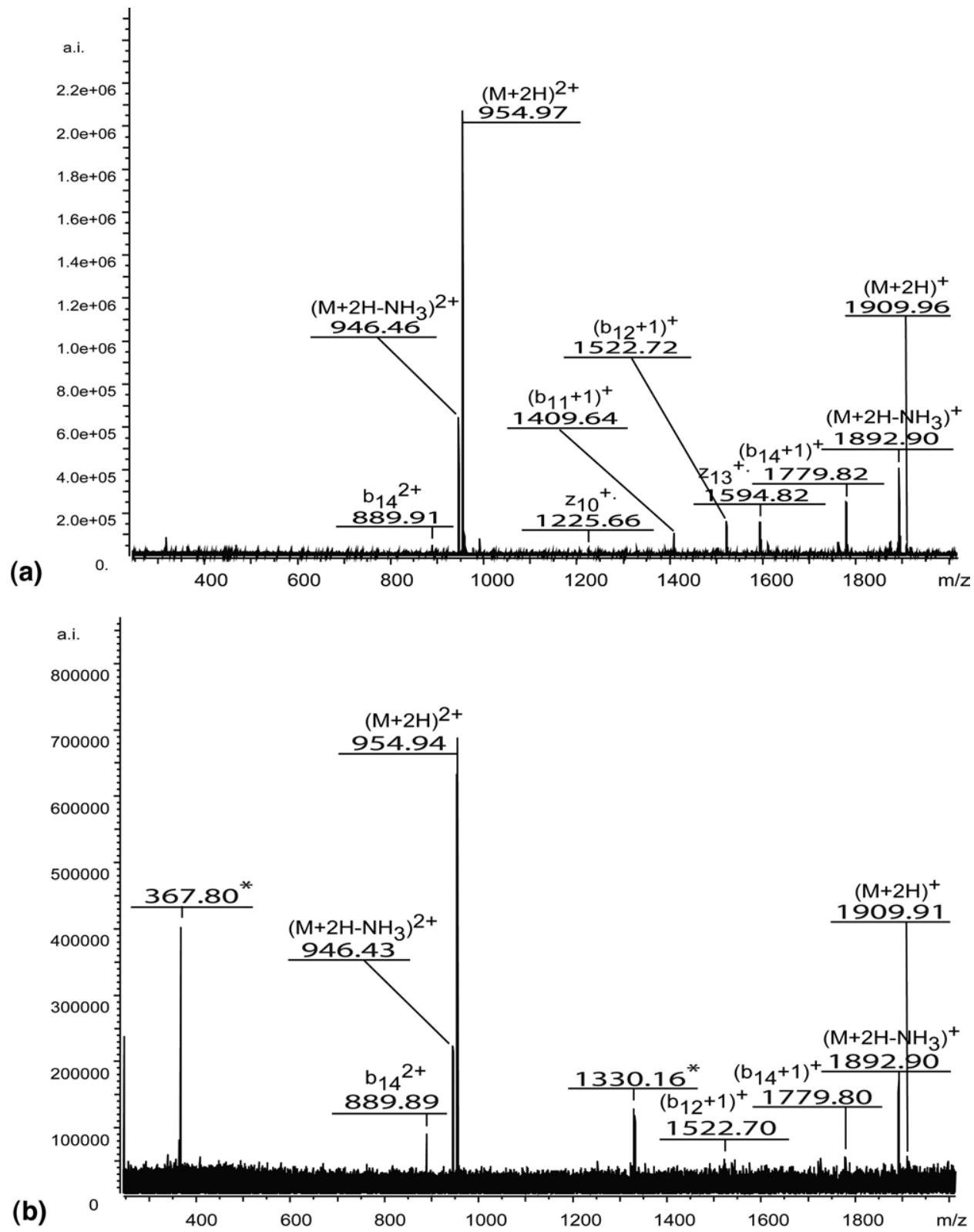

Figure 3. (a) IRMPD/ECD spectrum of $\left(\mathbf{P}_{\mathbf{1}}+2 \mathrm{H}\right)^{2+}$. (b) ECD/IRMPD spectrum $\left(\mathbf{P}_{\mathbf{1}}+2 \mathrm{H}\right)^{2+}$. ECD irradiation time was $150 \mathrm{~ms}$ with an electron beam energy of $4.5 \mathrm{eV}$. IRMPD irradiation time was 50 ms with a laser power of $15 \%$. Peaks labeled with asterisks were assigned and considered artifacts.

ions. The differences observed for $\mathbf{p}_{1}$ on the one hand and $p_{2}$ and $p_{3}$ on the other can be ascribed to the different amino acid sequence and, in particular, the presence in $\mathbf{p}_{2}$ and $\mathbf{p}_{3}$ of basic lysine residues that are the preferred protonation sites in the gas phase. In contrast, the pepy conjugates show practically no backbone fragmentations upon electron capture. When the ions were vibrationally excited by infrared photon absorption, electron capture induced fragmentations that were typical of charge-driven ion dissociations.

To explain this unusual behavior of the pepy conjugates, we investigated the electronic structure of the pepy moiety in model 2,2'-bipyridine-4-carboxamide and $4^{\prime}$-carboxyl-4-carboxamide systems (Structure 1,
Figure 6, and Structure 2, Figure 7). Protonation of the $2,2^{\prime}$-bipyridine system in $\mathbf{1}$ and $\mathbf{2}$ (pepy) can occur at either of the ring nitrogen atoms, $\mathrm{N}-1$ or $\mathrm{N}-1^{\prime}$, with similar proton affinities (PA) and gas-phase basicities (GB). This is illustrated by the similar energies of the isomeric ions $1 \mathrm{Ha}^{+}$and $\mathbf{1} \mathrm{Hb}^{+}$from $\mathbf{1}$, and $2 \mathrm{Ha}^{+}$, and $2 \mathbf{H b}^{+}$from 2 (Table 1). Note that the GB values for all the 2,2'-bipyridine derivatives are greater than those for peptides not containing basic amino acid residues where $\mathrm{GB}$ do not exceed $920 \mathrm{~kJ} \mathrm{~mol}^{-1}$, e.g., GB(AGG) = $895 \mathrm{~kJ} \mathrm{~mol}^{-1}$ [38] and GB(AAA) $=881-914 \mathrm{~kJ} \mathrm{~mol}^{-1}$ [38]. This indicates that the pepy moiety is the most basic and thus favored protonation site in conjugate $\mathbf{P}_{\mathbf{1}}$. Peptide conjugates $\mathbf{P}_{\mathbf{2}}$ and $\mathbf{P}_{\mathbf{3}}$ contain two basic lysine 


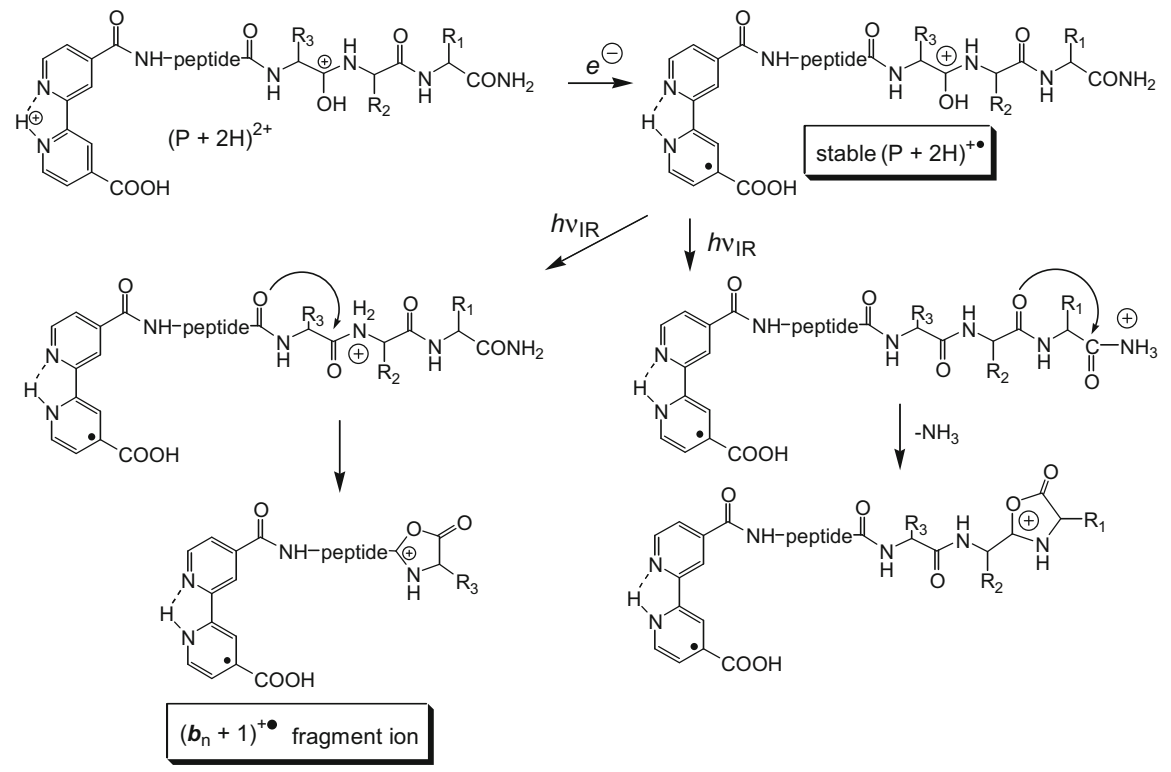

Scheme 1

residues. While one of those is likely to be protonated in the $(\mathbf{P}+2 \mathrm{H})^{2+}$ ions, the position of the other proton is less certain, because Coulomb repulsion effects may decrease the basicity of the other proximate Lys residue below that of the more remote pepy moiety. It is therefore reasonable to presume pepy protonation in the doubly and triply protonated ions derived from $\mathbf{P}_{\mathbf{2}}$ and $\mathbf{P}_{3}$ as well. It is also noteworthy that proton migration between the pepy $\mathrm{N}-1$ and $\mathrm{N}-\mathrm{1}^{\prime}$ nitrogen atoms has a very low activation energy $\left(30 \mathrm{~kJ} \mathrm{~mol}^{-1}\right)$ and thus the proton can be considered "mobile" in the sense of standard ion dissociation mechanisms [1].

Electron capture in the $(\mathbf{P}+2 \mathrm{H})^{2+}$ cations can proceed through intermediate electronic states $[22,23]$ to end up in the ground doublet state of the chargereduced ion. The nature of the ground state can be assessed from the calculated recombination energies for the protonated pepy residue, e.g., 5.08 to $5.30 \mathrm{eV}$ for the formation of radicals $\mathbf{1 H a}$ and $\mathbf{1 H b}$, respectively, and 5.46 to $5.43 \mathrm{eV}$ for $\mathbf{2} \mathbf{H a}$ and $\mathbf{2} \mathbf{H b}$, respectively (Table $\mathbf{1}$ ). These recombination energies are substantially greater than those in protonated peptides (3.71 to $4.18 \mathrm{eV}$ ) [15, $17,18]$. Hence, the energy data imply that the ground states of charge-reduced $\left(\mathbf{P}_{\mathbf{1}}-\mathbf{P}_{\mathbf{3}}+2 \mathrm{H}\right)^{+\cdot}$ ions have the odd electron confined in the pepy moiety. Molecular orbital and population analysis of the ground electronic state suggests that the radical site is indeed in the pepy $\pi$-system (Figure 8). The first two excited electronic states of pepy, $A$ and $B$, respectively, are $\pi^{*}$ states with excitation energies of 1.41 and $1.66 \mathrm{eV}$ above the ground $\pi$-state and radiative lifetimes of 160 and $253 \mathrm{~ns}$, respectively. Hence, the recombination energies for electron capture in the low-lying excited electronic states of protonated pepy, e.g., $\operatorname{RE}(A)=5.46-1.41=4.05 \mathrm{eV}$ and $\operatorname{RE}(B)=5.46-1.65=3.81 \mathrm{eV}$, are close to those for the protonated peptide part of the ion. This increases the probability of electron capture in the protonated pepy group and facilitates funneling the electron to the pepy moiety where it remains stored in a stable [pepy + $\mathrm{H}]$ radical system.

The recombination energies in the doubly and triply charged ions are increased by coulomb effects of the remaining positive charge, according to eq 1 . However, the Coulomb interactions are pair-wise and thus they affect the local recombination energies to the same extent. This means that the relative recombination energies of the individual protonated moieties stand virtually unchanged. The increase in the recombination energy in peptide ions due to Coulomb effects can be estimated as follows. Peptide conjugates $\mathbf{P}_{\mathbf{1}}-\mathbf{P}_{\mathbf{3}}$ were designed to assume $\alpha$-helix conformations in solution and were used for the construction of peptide bundles of well-defined tertiary structures [25b]. The actual conformations of gas-phase ions $\left(\mathbf{P}_{\mathbf{1}}-\mathbf{P}_{\mathbf{3}}+2 \mathrm{H}\right)^{2+}$ and their charge-reduced $\left(\mathbf{P}_{\mathbf{1}}-\mathbf{P}_{\mathbf{3}}+2 \mathrm{H}\right)^{+\cdot}$ counterparts have not been established, although the combination of hydrophobic (L, A, G) and acidic (E) residues is known to favor $\alpha$-helix conformations in gas-phase peptide ions [39]. Considering an $\alpha$-helical conformation of the peptide chain and placing one proton at pepy and the other at the second amino acid residue from the C-terminus (see above), the estimated distance between the charges is about $18 \AA$, resulting in a coulomb energy of $0.80 \mathrm{eV}$. Hence the estimated recombination energy in $\left(\mathbf{P}_{\mathbf{1}}+\right.$ $2 \mathrm{H})^{2+}$ is $5.46+0.80=6.26 \mathrm{eV}\left(604 \mathrm{~kJ} \mathrm{~mol}^{-1}\right)$.

The peptide conformation and the fact that the odd-electron is confined in the pepy moiety indicate that the charge site due to protonation and the radical site due to the presence of the odd electron are spatially remote in the charge-reduced ions, and their reactivity can be considered separately. The proton-induced dissociations are observed following IRMPD/ECD, where 
(a)

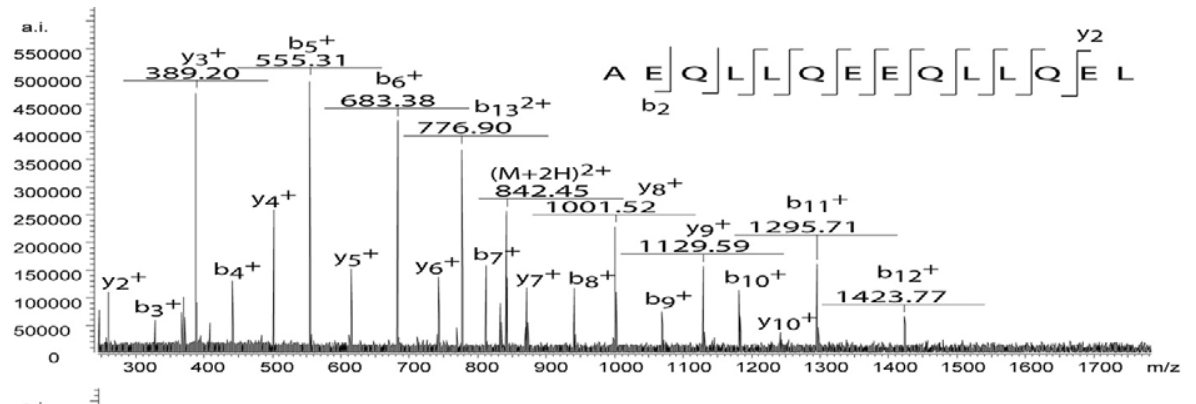

(b)

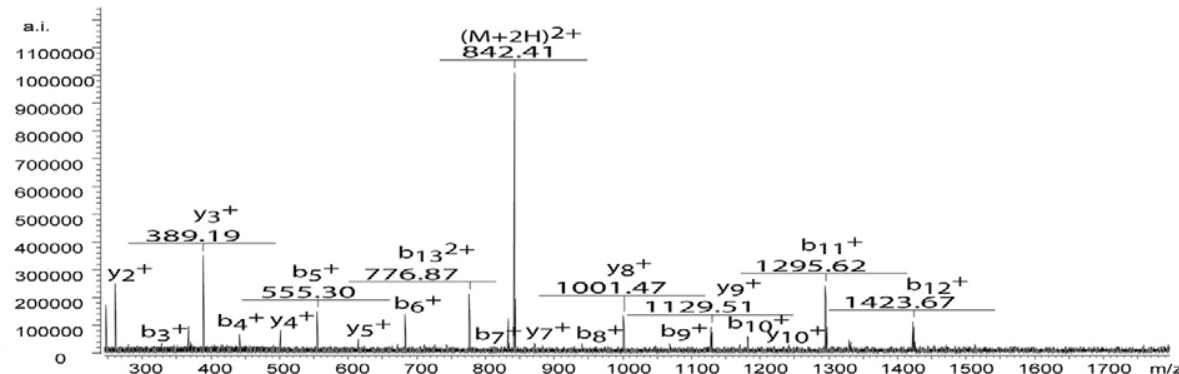

(c)

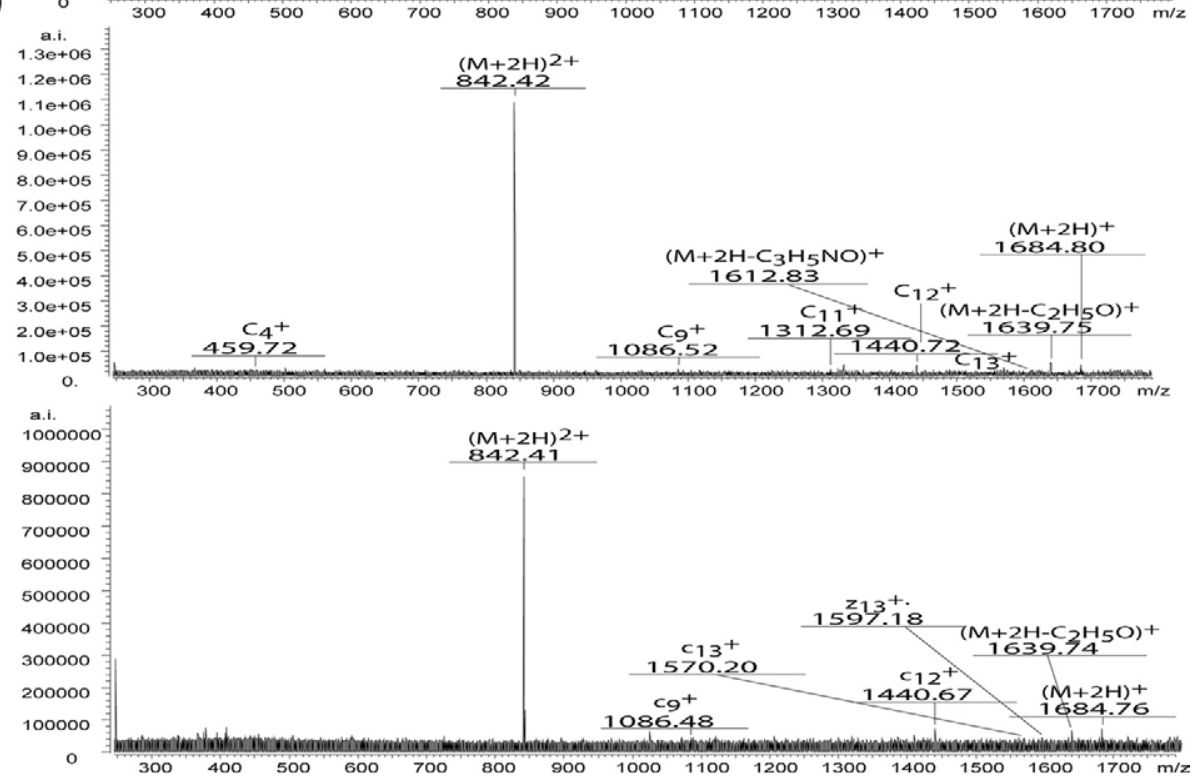

Figure 4. (a) CID mass spectrum of $\left(\mathrm{p}_{\mathbf{1}}+2 \mathrm{H}\right)^{2+}$. (b) IRMPD mass spectrum of $\left(\mathrm{p}_{\mathbf{1}}+2 \mathrm{H}\right)^{2+}$. IRMPD irradiation time was $75 \mathrm{~ms}$ at $35 \%$ laser power. (c) ECD mass spectrum of $\left(\mathbf{p}_{1}+2 \mathrm{H}\right)^{2+}$. ECD irradiation time was $150 \mathrm{~ms}$ with an electron beam energy of $4.5 \mathrm{eV}$. (d) ECD/IRMPD mass spectrum of $\left(\mathbf{p}_{\mathbf{1}}+\right.$ $2 \mathrm{H})^{2+}$. ECD irradiation time was $150 \mathrm{~ms}$ with an electron beam energy of $4.5 \mathrm{eV}$. IRMPD irradiation time was $15 \mathrm{~ms}$ at $15 \%$ laser power.

the recombination energy deposited in the chargereduced ion upon electron capture provides the requisite vibrational excitation. Analysis of the ion internal energy supports this hypothesis. A $\left(\mathbf{P}_{\mathbf{1}}+2 \mathrm{H}\right)^{2+}$ ion, which has 308 atoms and hence 918 vibrational degrees of freedom, has a mean ro-vibrational enthalpy that can be estimated according to the formula [40] $H_{\text {vib }} \cong 0.18 \times$ $(3 \mathrm{~N}-6) R T=410 \mathrm{~kJ} \mathrm{~mol}^{-1}$ at $298 \mathrm{~K}$. The energy received upon $\mathrm{ECD}\left(604 \mathrm{~kJ} \mathrm{~mol}^{-1}\right.$, vide supra) shifts the mean internal energy of the charge-reduced ion but does not broaden the internal energy distribution. The combined excitation causes dissociation of the highenergy tail of $\left(\mathbf{P}_{\mathbf{1}}+2 \mathrm{H}\right)^{+\cdot}$ by loss of ammonia, but the internal energy is insufficient to promote competitive backbone dissociations. Note that complete dissociation of $\left(\mathbf{P}_{\mathbf{1}}+2 \mathrm{H}\right)^{+\cdot}$ by loss of ammonia is accomplished by applying IR photons at low power prior to or after ECD. Backbone dissociations occur only when the $\left(\mathbf{P}_{\mathbf{1}}+\right.$ $2 \mathrm{H})^{2+}$ ions are preheated by infrared photon absorption at higher power to deposit additional $\sim 400 \mathrm{~kJ} \mathrm{~mol}^{-1}$.

The low reactivity of the radical site stems from the intrinsic stability of heterocyclic radicals when formed by collisional electron-transfer to protonated gas-phase molecules, as studied for pyridine [41], pyrimidine [42], and the nucleobases adenine [43], cytosine [44], and uracil $[45,46]$. With the 2,2'-bipyridine (bpy) systems, this was established experimentally by collisional electron-transfer to [bpy $+\mathrm{H}]^{+}$and detection of undis- 


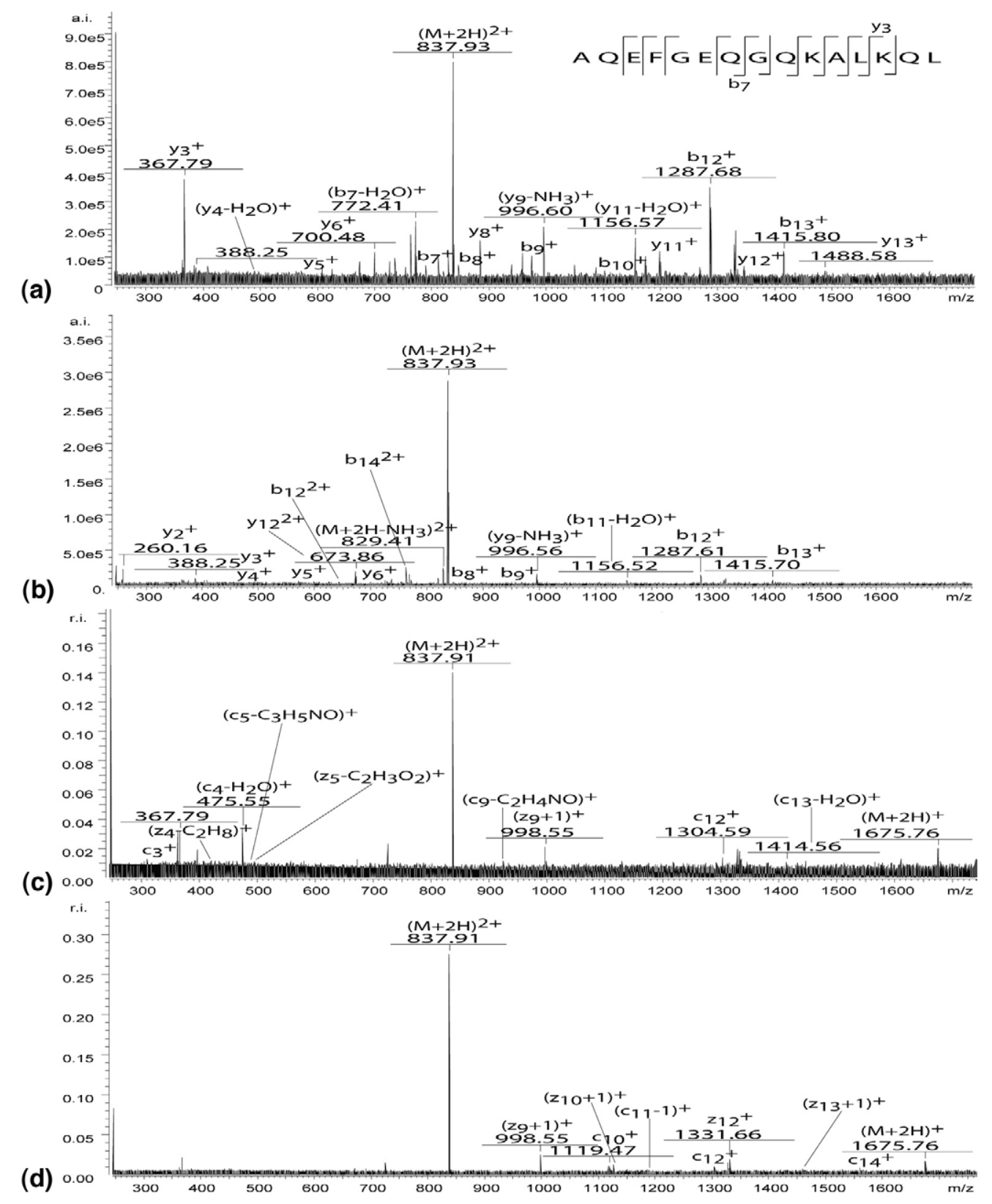

Figure 5. (a) CID mass spectrum of $\left(\mathbf{p}_{2}+2 \mathrm{H}\right)^{2+}$. (b) IRMPD mass spectrum of $\left(\mathbf{p}_{2}+2 \mathrm{H}\right)^{2+}$. IRMPD irradiation time was $150 \mathrm{~ms}$ at $35 \%$ laser power. (c) ECD mass spectrum of $\left(\mathrm{p}_{2}+2 \mathrm{H}\right)^{2+}$. ECD irradiation time was $250 \mathrm{~ms}$ with an electron beam energy of $4.5 \mathrm{eV}$. (d) ECD/IRMPD mass spectrum of $\left(\mathbf{p}_{2}+2 \mathrm{H}\right)^{2+}$. ECD irradiation time was $250 \mathrm{~ms}$ with an electron beam energy of $4.5 \mathrm{eV}$. IRMPD irradiation time was $15 \mathrm{~ms}$ at $15 \%$ laser power.

sociated (bpy $+\mathrm{H}) \cdot$ radicals following collisional reionization (Figure 9). The stability of the analogous (pepy $+\mathrm{H})^{\circ}$ radicals is indicated by the substantial endothermicity for the loss of $\mathrm{H}\left(159-161 \mathrm{~kJ} \mathrm{~mol}^{-1}\right)$, and the fact that the $\mathrm{N}-\mathrm{H}$ bond dissociation is likely to require an energy barrier in the transition state. The latter is estimated to be as high as $40 \mathrm{~kJ} \mathrm{~mol}^{-1}$ above the dissociation thermochemical threshold, or $160+40=$ $200 \mathrm{~kJ} \mathrm{~mol}^{-1}$ above the reactant, as established for other heterocyclic radicals [41-47]. The binding energy of the hydrogen atom in the pepy moiety substantially exceeds the hydrogen atom affinities of peptide amide groups, which have been calculated to range between 21-41 $\mathrm{kJ} \mathrm{mol}^{-1}$ [15]. This implies that the hydrogen atom is trapped in the charge-reduced pepy radical and is not readily available for transfer to the peptide chain to trigger $\mathrm{N}-\mathrm{C}_{\alpha}$ bond dissociations. In addition, the activation energy for the pepy radical dissociations is greater than the activation energies for peptide ion dissociations leading to $\mathbf{b}$ ions $\left(100-160 \mathrm{~kJ} \mathrm{~mol}^{-1}\right)[2,5]$. This explains why charge-reduced $\left(\mathbf{P}_{\mathbf{1}}-\mathbf{P}_{3}+2 \mathrm{H}\right)^{+}$ions undergo predominant ion dissociations.

The energy analysis can be summarized as follows. We have shown that electron capture in the peptide dications 


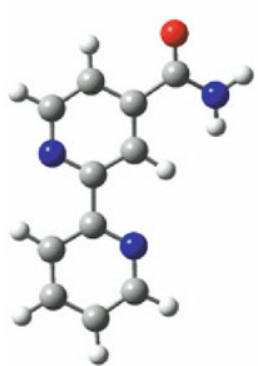

1

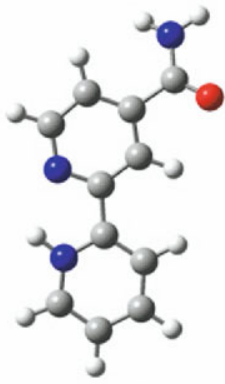

$1 \mathrm{Ha}^{+}$

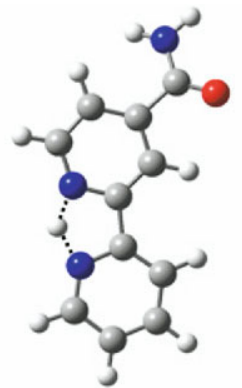

TS1

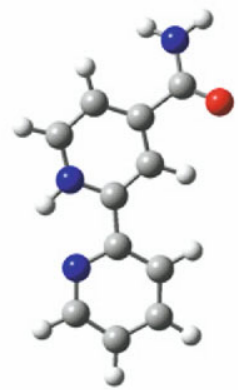

$1 \mathrm{Hb}^{+}$

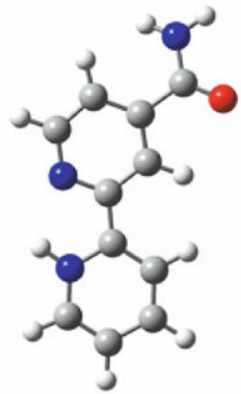

$1 \mathrm{Ha}$

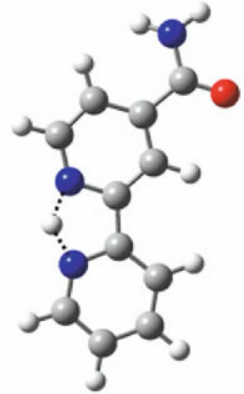

TS2

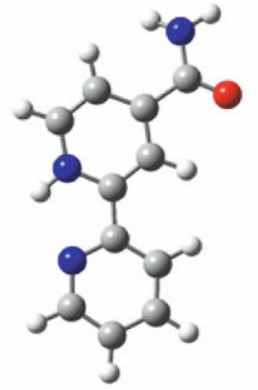

$1 \mathrm{Hb}$

Figure 6. B3LYP/6-31 $+\mathrm{G}(\mathrm{d}, \mathrm{p})$ optimized structures of 2,2'-bipyridine-4-carboxamide, ions, and radicals.

proceeds to the ground electronic state of the chargereduced ion. This finding is of fundamental importance because it shows for the first time that the ground state is accessed upon electron capture in a major fraction of multiply protonated peptide ions. The special nature of the pepy-modified peptides is that the charge-reduced

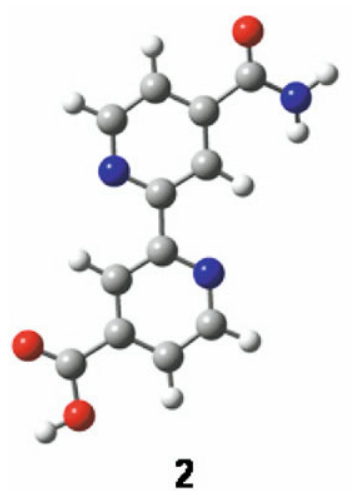

2

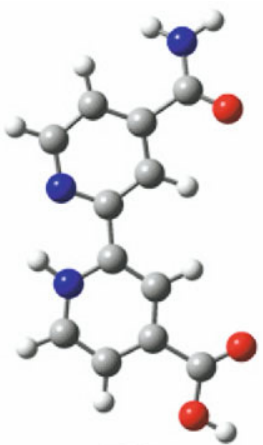

$2 \mathrm{Ha}^{+}$

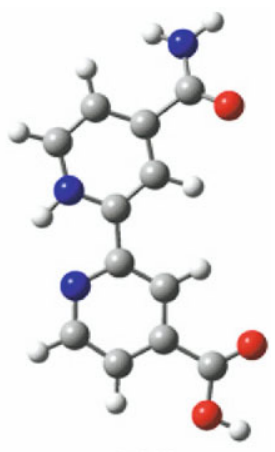

$\mathbf{2} \mathrm{Hb}^{+}$
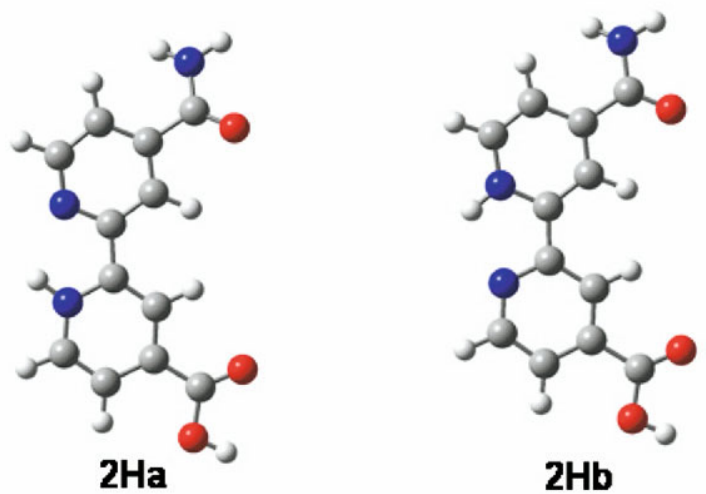

Figure 7. B3LYP/6-31 + G(d,p) optimized structures of 2,2'-bipyridine-4-carboxyl-4'-carboxamide, ions, and radicals. 
Table 1. Energy data for 2,2'-bipyridine derivatives relative energy $^{\mathrm{a}, \mathrm{b}}$

\begin{tabular}{lcc}
\hline Species/reaction & $\begin{array}{c}\text { B3LYP/6-31 } \\
\text { G(d,p) }\end{array}$ & $\begin{array}{c}\text { B3-PMP2/6-311 } \\
++\mathrm{G}(3 \mathrm{df}, 2 \mathrm{p})\end{array}$ \\
\hline \hline $1 \mathrm{Ha}^{+} \rightarrow 1+\mathrm{H}^{+}$ & 971 & 963 \\
& $978^{\mathrm{c}}$ & $970^{\mathrm{c}}(937)^{\mathrm{d}}$ \\
$1 \mathrm{Hb}^{+} \rightarrow 1+\mathrm{H}^{+}$ & 965 & 958 \\
& $972^{\mathrm{c}}$ & $965^{\mathrm{c}}(932)^{\mathrm{d}}$ \\
$1 \mathrm{Ha}^{+} \rightarrow \mathrm{TS} 1$ & 30 & 30 \\
$1 \mathrm{Ha} \rightarrow 1+\mathrm{H}^{\bullet}$ & 166 & 137 \\
$1 \mathrm{Hb} \rightarrow 1+\mathrm{H}^{\bullet}$ & 182 & 154 \\
$1 \mathrm{Ha} \rightarrow \mathrm{TS} 2$ & 40 & 49 \\
$2 \mathrm{Ha} \rightarrow 2+\mathrm{H}^{+}$ & 955 & 950 \\
& $963^{\mathrm{c}}$ & $956^{\mathrm{c}}(923)^{\mathrm{d}}$ \\
$2 \mathrm{Hb}^{+} \rightarrow 2+\mathrm{H}^{+}$ & 956 & 950 \\
& $962^{\mathrm{c}}$ & $956^{\mathrm{c}}(923)^{\mathrm{d}}$ \\
$2 \mathrm{Ha}^{+}+2+\mathrm{H}^{\bullet}$ & 194 & 161 \\
$2 \mathrm{Ha}^{+}+2+\mathrm{H}^{\bullet}$ & 185 & 159 \\
$1 \mathrm{Ha}^{+}+\mathrm{e}^{-} \rightarrow 1 \mathrm{Ha}$ & $-509(5.27)^{\mathrm{e}}$ & $-490(5.08)^{\mathrm{e}}$ \\
$1 \mathrm{Hb}^{+}+\mathrm{e}^{-} \rightarrow 1 \mathrm{Hb}$ & $-530(5.50)^{\mathrm{e}}$ & $-511(5.30)^{\mathrm{e}}$ \\
$2 \mathrm{Ha}^{+}+\mathrm{e}^{-} \rightarrow 2 \mathrm{Ha}$ & $-552(5.72)^{\mathrm{e}}$ & $-526(5.46)^{\mathrm{e}}$ \\
$2 \mathrm{Hb}^{+}+\mathrm{e}^{-} \rightarrow 2 \mathrm{Hb}$ & $-542(5.62)^{\mathrm{e}}$ & $-524(5.43)^{\mathrm{e}}$ \\
\hline
\end{tabular}

${ }^{\text {a}} \mathrm{All}$ energies are in units of kilojoule per mole unless stated otherwise. bIncluding B3LYP/6-31 + G(d,p) zero-point vibrational energy corrections and referring to $0 \mathrm{~K}$.

cProton affinities at $298 \mathrm{~K}$

${ }^{\mathrm{d}}$ Gas-phase basicities at $298 \mathrm{~K}$.

${ }^{\mathrm{e} A d i a b a t i c ~ r e c o m b i n a t i o n ~ e n e r g i e s ~ i n ~} \mathrm{eV}$

pepy group is stable, which allows us to identify the ground state of the peptide cation-radicals, as discussed above. The question arises of how the electron reaches the ground electronic state. According to an analysis of a nonpeptide model system [23c], the electron can follow a cascade of nonradiative transfers due to potential curve crossings or conical intersections and thus be funneled into a particular electronic state. Our data indicate that as the electron is cascading down the excited-state manifold, it avoids dissociative states that were postulated to be

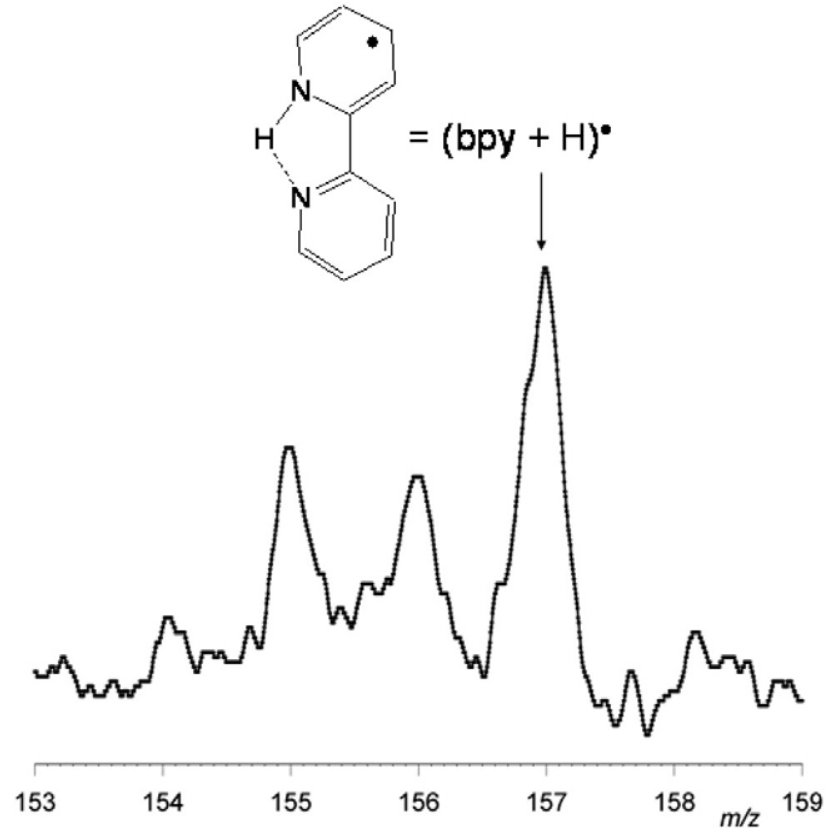

Figure 9. Neutralization-reionization mass spectrum of protonated $2,2^{\prime}$-bipyridine showing the undissociated radical after ionization at $\mathrm{m} / \mathrm{z} 157$.

involved in the hypothetical nonergodic dissociation [13]. In contrast, the present experimental data show that the electron reaches the ground electronic state, and the recombination energy deposited upon ECD causes ergodic dissociations.

Should the nonergodic hypothesis of ECD be completely discarded [6]? It remains to be established by experiments and theory whether the ergodic behavior observed for the present systems is a general feature of ECD. Peptide derivatization can change dissociations upon electron capture. For example, recent experiments

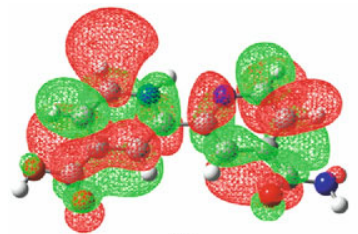

$65 \alpha$

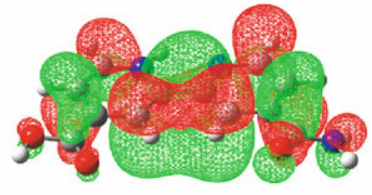

$66 \alpha$

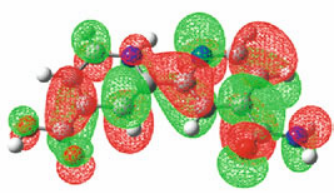

$68 \alpha$

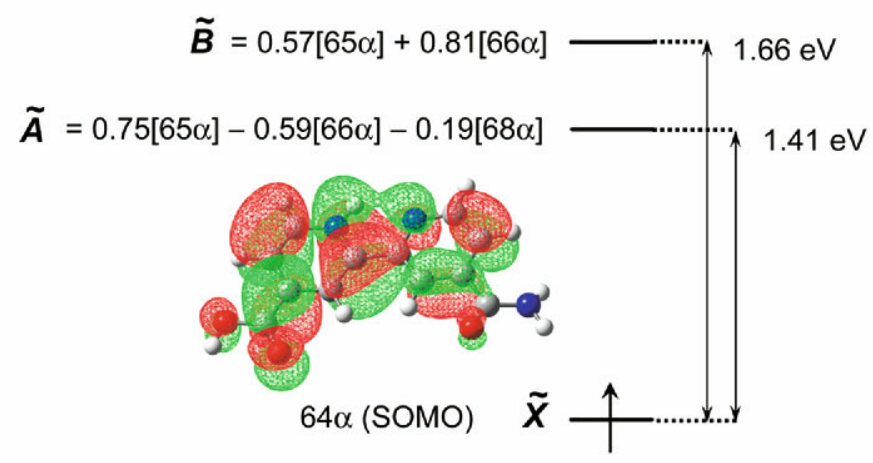

Figure 8. Molecular orbitals and spin densities in $2 \mathrm{Ha}$ and $2 \mathrm{Hb}$ radicals. 
with ECD of coumarin-derivatized Substance P showed an increase of side-chain bond cleavages and a decrease of peptide backbone dissociations in the presence of one or two coumarin moieties in the derivatized peptide [48]. We note that the difference between the pepy and coumarin units is that the latter has a low electron affinity $(<0.5 \mathrm{eV})$ [49] and thus cannot work as an electron trap. New computational data on charge-reduced peptides indicate that the unpaired electron density is spread over the cation-radical by quantum interference of near-degenerate electronic states that make the electron available even at mutually remote parts of the ion [50]. Possibly, the presence of a low-lying ground electronic state in $\left(\mathbf{P}_{\mathbf{1}}-\mathbf{P}_{\mathbf{3}}+\right.$ $2 \mathrm{H})^{+\cdot}$ prevents such interactions and renders the electron nonreactively parked in the pepy moiety. The present data also indirectly emphasize the importance of $\mathrm{N}-\mathrm{C}_{\alpha}$ bond weakening upon ECD due to the formation of aminoketyl radical intermediates that was predicted and quantified by previous calculations [16, 17, 19]. When the formation of aminoketyl radical intermediates is prevented by the presence of a stable electron or hydrogen atom trap, backbone dissociation is hampered [48] or suppressed.

\section{Conclusions}

In light of the energy data, the factors affecting the dissociations of pepy-peptide conjugates can be summarized as follows. Electron capture in the peptide cations proceeds to the ground electronic state of the charge-reduced ion where the radical site is sequestered in the pepy moiety, which is intrinsically stable and does not undergo dissociation. The combined vibrational energy of the precursor ion and the recombination energy acquired upon electron capture are distributed as vibrational energy and utilized to induce the lowest-energy ion dissociations by loss of ammonia and backbone cleavages in a fraction of charge-reduced ions. The backbone cleavages take place in positions remote from the radical site and form $\mathbf{b}_{\mathrm{n}}+1$ fragment ions, where the +1 Da mass increment is due to the nonreactive hydrogen atom in the pepy moiety. This chemistry resembles the spin-remote dissociations that were reported previously for amino acid cation-radicals containing 2,2'-bipyridine ligands [51]. Perhaps most significantly, the fact that charge-driven peptide backbone dissociations are triggered at sites that are remote from the site of electron capture represents a clear example of internal conversion of the recombination energy and vibrational energy redistribution over a large polyatomic system. This provides a textbook example of ergodic behavior upon electron capture.

\section{Acknowledgments}

FT thanks the National Science Foundation for research support through grants CHE-0349595 for experiments and CHE-0342956 for calculations. The Computational Chemistry Facility has received joint support from NSF and University of Washington. DRG thanks the NIAID WWAMI Regional Center of Excellence for Biodefense and Emerging Infectious Diseases, 1U54AI5714101, and the UW NIEHS Center for Ecogenetics and Environmental Health, 5P30ES007033-10. Thanks are due to Dr. Erik A. Syrstad for the measurement of the ${ }^{+} \mathrm{NR}^{+}$mass spectrum of $($bpy $+\mathrm{H})$.

\section{References}

1. (a) Burlet, O.; Yang, C. Y.; Gaskell, S. J. Influence of Cysteine to Cysteic Acid Oxidation on the Collision-Activated Decomposition of Protonated Peptides: Evidence for Intraionic Interactions. J. Am. Soc. Mass Spectrom. 1992, 3, 337-344. (b) Dongre, A. R.; Jones, J. L.; Somogyi, A.; Wysocki, V. H. Influence of Peptide Composition, Gas-Phase Basicity, and Chemical Modification on Fragmentation Efficiency: Evidence for the Mobile Proton Model. J. Am. Chem. Soc. 1996, 118, 8365-8374.

2. Paizs, B.; Lendvay, G.; Vekey, K.; Suhai, S. Formation of $b_{2}^{+}$Ions from Protonated Peptides: An ab Initio Study. Rapid Commun. Mass Spectrom. 1999, 13, 525-533.

3. Csonka, I. P.; Paizs, B.; Lendvay, G.; Suhai, S. Proton Mobility in Protonated Peptides: A Joint Molecular Orbital and RRKM Study. Rapid Commun. Mass Spectrom. 2000, 14, 417-431.

4. El Aribi, H.; Orlova, G.; Rodriquez, C. F.; Almeida, D. R. P.; Hopkinson, A. C.; Siu, K. W. M. Fragmentation Mechanisms of Product Ions from Protonated Tripeptides. J. Phys. Chem. B 2004, 108, 18743-18749.

5. (a) Paizs, B.; Suhai, S. Fragmentation Pathways of Protonated Peptides. Mass Spectrom. Rev. 2005, 24, 508-548. (b) Wysocki, V. H.; Cheng, G.; Zhang, Q.; Herrmann, K. A.; Beardsley, R. L.; Hildebrand, A. E. Peptide Gragmentation Overview. In Principles of Mass Spectrometry Applied to Biomolecules; Laskin, J.; Lifshitz, C., Eds.; Wiley-Interscience: Hoboken, New Jersey, 2006; Part II, Chap VIII, pp 279-300.

6. Lifshitz, C. Intramolecular Vibrational Energy Redistribution and Ergodicity of Biomolecular Dissociation. In Principles of Mass Spectrometry Applied to Biomolecules; Laskin, J.; Lifshitz, C., Eds.; Wiley-Interscience: Hoboken, New Jersey, 2006; Part I, Chap VII, pp 239-275.

7. Gilbert, R. G.; Smith, S. C. Theory of Unimolecular and Recombination Reactions; Blackwell Scientific Publications: Oxford, 1990; pp 52-132

8. Glasstone, S.; Laidler, K. J.; Eyring, H. The Theory of Rate Processes; the Kinetics of Chemical Reactions, Viscosity, Diffusion, and Electrochemical Phenomena. McGraw-Hill: New York; 1941.

9. Hu, Y.; Hadas, B.; Davidovitz, M.; Balta, B.; Lifshitz, C. Does IVR Take Place Prior to Peptide Ion Dissociation? J. Phys. Chem. A 2003, 107, 6507-6514.

10. (a) McLuckey, S. A.; Goeringer, D. E. Slow Heating Methods in Tandem Mass Spectrometry. J. Mass Spectrom. 1997, 32, 461-474. (b) Goeringer, D. E.; McLuckey, S. A. Relaxation of Internally Excited High-Mass Ions Simulated Under Typical Quadrupole Ion Trap Storage Conditions. Int. J. Mass Spectrom. 1998, 177, 163-174.

11. Zubarev, R. A.; Kelleher, N. L.; McLafferty, F. W. Electron Capture Dissociation of Multiply Charged Protein Cations. A Nonergodic Process. J. Am. Chem. Soc. 1998, 120, 3265-3266.

12. Coon, J. J.; Ueberheide, B.; Syka, J. E. P.; Dryhurst, D. D.; Ausio, J.; Shabanowitz, J.; Hunt, D. F. Protein Identification Using Sequential Ion/Ion Reactions and Tandem Mass Spectrometry. Proc. Natl. Acad. Sci. U.S.A. 2005, 102, 9463-9468.

13. Zubarev, R. A.; Horn, D. M.; Fridriksson, E. K.; Kelleher, N. L.; Kruger, N. A.; Lewis, M. A.; Carpenter, B. K.; McLafferty, F. W. Electron Capture Dissociation for Structural Characterization of Multiply Charged Protein Cations. Anal. Chem. 2000, 72, 563-573.

14. (a) Cooper, H. J.; Hakansson, K.; Marshall, A. G. The Role of Electron Capture Dissociation in Biomolecular Analysis. Mass Spectrom. Rev. 2005, 24, 201-222. (b) Cooper, H. J. Investigation of the Presence of b-Ions in Electron Capture Dissociation Mass Spectra. J. Am. Soc. Mass Spectrom. 2005, 16, 1932-1940. (c) Fung, Y. M. E.; Chan, T.-W. D. Experimental and Theoretical Investigations of the Loss of Amino Acid Side Chains in Electron Capture Dissociation of Model Peptides. J. Am. Soc. Mass Spectrom. 2005, 16, 1523-1535.

15. Tureček, F.; Syrstad, E. A. Mechanism and Energetics of Intramolecular Hydrogen Transfer in Amide and Peptide Radicals and CationRadicals. J. Am. Chem. Soc. 2003, 125, 3353-3369.

16. Tureček, F. N-C C $-C_{\alpha}$ Bond Dissociation Energies and Kinetics in Amide and Peptide Radicals. Is the Dissociation a Nonergodic Process? J. Am. Chem. Soc. 2003, 125, 5954-5963.

17. Chen. X.; Tureček, F. The Arginine Anomaly. Arginine Radicals are Poor Hydrogen Atom Donors in Electron Transfer Induced Dissociations. J. Am. Chem. Soc. 2006, 128, 12520-12530.

18. Nguyen, V. Q.; Tureček, F. Protonation Sites in Gaseous Pyrrole and Imidazole: A Neutralization-Reionization and ab Initio Study. J. Mass Spectrom. 1996, 31, 1173-1184.

19. Tureček, F.; Syrstad, E. A.; Seymour, J. L.; Chen, X.; Yao, C. Peptide Cation-Radicals. A Computational Study of the Competition Between Peptide $\mathrm{N}-\mathrm{C}_{\alpha}$ bond cleavage and loss of the side chain in the [GlyPhe- $\left.\mathrm{NH}_{2}+2 \mathrm{H}\right]^{+\cdot}$ Cation-Radical. J. Mass Spectrom. 2003, 38, 1093-1104.

20. Bakken, V.; Helgaker, T.; Uggerud, E. Models of Fragmentations Induced by Electron Attachment to Protonated Peptides.Eur. J. Mass Spectrom. 2004, 10, 625-638. 
21. Konishi, H.; Yokotake, Y.; Ishibashi, T. Theoretical Study on the Electron Capture Dissociation Correlated with Proton Transfer Processes.J. Mass Spectrom. Soc. Jpn. 2002, 50, 222-225.

22. Syrstad, E. A.; Tureček, F. Toward a General Mechanism of Electron Capture Dissociation. J. Am. Soc. Mass Spectrom. 2005, 16, 208-224.

23. (a) Sobczyk, M.; Anusiewicz, I.; Berdys-Kochanska, J.; Sawicka, A.; Skurski, P.; Simons, J. Coulomb-Assisted Dissociative Electron Attachment: Application to a Model Peptide. J. Phys. Chem. A 2005, 109, 250-258. (b) Anusiewicz, I.; Berdys-Kochanska, J.; Simons, J. Electron Attachment Step in Electron Capture Dissociation (ECD) and Electron Transfer Dissociation (ETD). J. Phys. Chem. A 2005, 109, 5801-5813. (c) Anusiewicz, I.; Berdys-Kochanska, J. A; Skurski, P.; Simons, J. Simulating Electron Transfer Attachment to a Positively Charged Model Peptide. J. Phys. Chem. A 2006, 110, 1261-1266. (d) Sobczyk, M.; Simons, J. The Role of Excited Rydberg States in Electron Transfer Dissociation. J. Phys. Chem. B 2006 110, 7519-7527.

24. Breuker, K.; Oh, H.-B.; Lin, C.; Carpenter, B. K.; McLafferty, F. W. Nonergodic and Conformational Control of the Electron Capture Dissociation of Protein Cations. Proc. Natl. Acad. Sci. U.S.A. 2004, 101, 14011-14016.

25. (a) Lieberman, M.; Sasaki, T. Iron(II) Organizes a Synthetic Peptide into Three-Helix Bundles. I. Am. Chem. Soc. 1991, 113, 1470-1471. (b) Lieberman, M.; Tabet, M.; Sasaki, T. Dynamic Structure and Potential Energy Surface of a Three-Helix Bundle Protein. J. Am. Chem. Soc. 1994, 116, 5035-5044.. (c) Sasaki, T.; Lieberman, M. Between the Secondary Structure and the Tertiary Structure Falls the Globule: A Problem in de Novo Protein Design. Tetrahedron 1993, 49, 3677-3689.

26. Caravatti, P; Allemann, M. The Infinity Cell-A New Trapped-Ion Cell with Radiofrequency Covered Trapping Electrodes for FourierTransform Ion-Cyclotron Resonance Mass Spectrometry. Org. Mass Spectrom. 1991, 26, 514-518.

27. Tureček, F.; Gu, M.; Shaffer, S. A. A Novel Tandem Quadrupole Acceleration-Deceleration Mass Spectrometer for NeutralizationReionization Studies. J. Am. Soc. Mass Spectrom. 1992, 3, 493-501.

28. Seymour, J. L.; Syrstad, E. A.; Langley, C. C.; Tureček, F. NeutralizationReionization of Ions Produced by Electrospray. Instrument Design and Initial Data. Int. J. Mass Spectrom. 2003, 228, 687-702.

29. Tureček, F. Transient Intermediates of Chemical Reactions by Neutralization-Reionization Mass Spectrometry. Top Curr. Chem. 2003, 225, 77-129.

30. Tureček, F. The Modern Mass Spectrometer. A Laboratory for Unstable Neutral Species. Org. Mass Spectrom. 1992, 27, 1087-1097.

31. Frisch, M. J.; Trucks, G. W.; Schlegel, H. B.; Scuseria, G. E.; Robb, M. A.; Cheeseman, J. R.; Montgomery, J. A., Jr.; Vreven, T.; Kudin, K. N.; Burant, J. C.; Millam, J. M.; Iyengar, S. S.; Tomasi, J.; Barone, V.; Mennucci, B.; Cossi, M.; Scalmani, G.; Rega, N.; Petersson, G. A.; Nakatsuji, H.; Hada, M.; Ehara, M.; Toyota, K.; Fukuda, R.; Hasegawa, J.; Ishida, M.; Nakajima, T.; Honda, Y.; Kitao, O.; Nakai, H.; Klene, M.; Li, X.; Knox, J. E.; Hratchian, H. P.; Cross, J. B.; Adamo, C.; Jaramillo, J.; Gomperts, R.; Stratmann, R. E.; Yazyev, O.; Austn, A. J.; Cammi, R.; Pomelli, C.; Ochterski, J., W.; Ayala, P. Y.; Morokuma, K.; Voth, G. A.; Salvador, P.; Dannenberg, J. J.; Zakrzewski, V. G.; Dapprich, S.; Daniels, A. D.; Strain, M. C.; Farkas, O.; Malick, D. K.; Rabuck, A. D.; Raghavachari, K.; Foresman, J. B.; Ortiz, J. V.; Cui, Q.; Baboul, A. G.; Clifford, S.; Cioslowski, J.; Stefanov, B. B.; Liu, G.; Liashenko, A.; Piskorz, P.; Komaromi, I.; Martin, R. L.; Fox, D. J.; Keith, T.; Al-Laham, M. A.; Peng, C. Y.; Nanayakkara, A.; Challacombe, M.; Gill, P. M. W.; Johnson, B.; Chen, W.; Wong, M. W.; Gonzalez, C.; Pople, J. A. Gaussian 03, Revision B, 05; Gaussian, Inc.: Pittsburgh, PA, 2003.

32. (a) Becke A. D. A New Mixing of Hartree-Fock and Local-DensityFunctional Theories. J. Chem. Phys. 1993, 98, 1372-1377. (b) Becke A. D. Density Functional Thermochemistry. III. The Role of Exact Exchange. J. Chem. Phys. 1993, 98, 5648-5652. (c) Stephens P. J.; Devlin F. J.; Chabalowski C. F.; Frisch M. J. Ab Initio Calculation of Vibrational Absorption and Circular Dichroism Spectra Using Density Functional Force Fields. J. Phys. Chem. 1994 98, 11623-11627.

33. Tureček, F.; Cramer, C. J. Thermochemistry of Simple Enols and Enol Cation-Radicals Revisited. A G2(MP2) ab Initio Study. J. Am. Chem. Soc. 1995, 117, 12243-12253.

34. Møller, C.; Plesset, M. S. Note on an Approximation Treatment for Many-Electron Systems. Phys. Rev. 1934, 46, 618-622.

35. Tureček, F. Proton Affinity of Dimethyl Sulfoxide and Relative Stabilities of $\mathrm{C}_{2} \mathrm{H}_{6} \mathrm{OS}$ Molecules and $\mathrm{C}_{2} \mathrm{H}_{7} \mathrm{OS}^{+}$Ions. A Comparative G2(MP2) $\mathrm{ab}$ Initio and Density Functional Theory Study. J. Phys. Chem. A 1998, 102, 4703-4713.
36. (a) Tureček, F.; Wolken, J. K. Dissociation Energies and Kinetics of Aminopyrimidinium Radicals by ab Initio and Density Functional Theory. J. Phys. Chem. A 1999, 103, 1905-1912. (b) Tureček, F.; Wolken, J. K.; Sadílek, M. Distinction of Isomeric Pyridyl Cations and Radicals by Neutralization-Reionization Mass Spectrometry, ab Initio and Density Functional Theory Calculations. Eur. Mass Spectrom. 1998, 4, 321332. (c) Wolken, J. K.; Tureček, F. Heterocyclic Radicals in the Gas Phase. An Experimental and Computational Study of 3-Hydroxypyridinium Radicals and Cations. J. Am. Chem. Soc. 1999, 121, 6010-6018. (d) Wolken, J. K.; Tureček, F. Modeling Nucleobase Radicals in the Gas Phase. Experimental and Computational Study of 2-Hydroxypyridinium and 2(1H)-Pyridone Radicals. I. Phys. Chem. A 1999, 103 , 6268-6281. (e) Tureček, F.; Carpenter, F. H. Glycine Radicals in the Gas Phase. J. Chem. Soc., Perkin. Trans. 2 1999, 2315-2323. (f) Polášek, M.; Tureček, F. Hydrogen Atom Adducts to Nitrobenzene: Formation of the Phenylnitronic Radical in the Gas Phase and Energetics of Wheland Intermediates. J. Am. Chem. Soc. 2000, 122, 9511-9524.

37. (a) Rablen, P. R. Is the Acetate Anion Stabilized by Resonance or Electrostatics? A Systematic Structural Comparison. J. Am. Chem. Soc. 2000, 122, 357-368. (b) Rablen, P. R.; Bentrup, K. H. Are the Enolates of Amides and Esters Stabilized by Electrostatics? J. Am. Chem. Soc. 2003 125, 2142-2147. (c) Rablen, P. R. Is the Acetate Anion Stabilized by Resonance or Electrostatics? A Systematic Structural Comparison. J. Am Chem. Soc. 2000, 122, 357-368. (d) Rablen, P. R. Computational Analysis of the Solvent Effect on the Barrier to Rotation about the Conjugated $\mathrm{C}-\mathrm{N}$ Bond in Ethyl N,N-Dimethylcarbamate. J. Org. Chem. 2000, 65 7930-7937. (e) Hirama, M.; Tokosumi, T.; Ishida, T.; Aihara, J. Possible Molecular Hydrogen Formation Mediated by the Inner and Outer Carbon Atoms of Typical PAH Cations. Chem. Phys. 2004, 305, 307-316. (f) Fung, Y. M. E.; Liu, H.; Chan, T. W. D. Electron Capture Dissociation of Peptides Metalated with Alkaline-Earth Metal Ions. J. Am. Soc. Mass Spectrom. 2006, 17, 757-771.

38. Harrison, A. G. The Gas-Phase Basicities and Proton Affinities of Amino Acids and Peptides. Mass Spectrom. Rev. 1997, 16, 201-217.

39. (a) a)Hudgins, R. R.; Ratner, M. A.; Jarrold, M. F. Design of Helices that are Stable in Vacuo. I. Am. Chem. Soc. 1998, 120, 12974-12975. (b) Hartings, M. R.; Kinnear, B. S.; Jarrold, M. F. The Energy Landscape of Unsolvated Peptides: The Role of Context in the Stability of Alanine/ Glycine Helices. J. Am. Chem. Soc. 2003, 125, 3941-3947.

40. Tureček, F. Temperature Effects in Mass Spectrometry. Estimation of Thermal Energies of Organic Molecules. Org. Mass Spectrom. 1991, 26 , 1074-1081.

41. Nguyen, V. Q.; Tureček, F. Gas-Phase Protonation of Pyridine. A Variable-Time Neutralization-Reionization and ab Initio Study of Pyridinium Radicals. J. Mass Spectrom. 1997, 32, 55-63.

42. Nguyen, V. Q.; Tureček, F. Protonation Sites in Pyrimidine and Pyrimidinamines in the Gas Phase. I. Am. Chem. Soc. 1997, 119, 2280-2290.

43. Chen, X.; Syrstad, E. A.; Nguyen, M. T.; Gerbaux, P.; Tureček, F. Adenine Radicals in the Gas Phase. An Experimental and Computational Study of Hydrogen Atom Adducts to Adenine. J. Phys. Chem. A 2005, 109, 8121-8132.

44. Yao, C.; Cuadrado-Peinado, M.; Polášek, M.; Tureček, F. Specific Generation of 1-Methylcytosine Radicals in the Gas-Phase. Angew. Chem. Int. Ed. Engl. 2005, 44, 6708-6711.

45. Wolken, J K.; Tureček, F. Direct Observation of a Hydrogen Atom Adduct to O-4 in Uracil. A Neutralization-Reionization Mass Spectrometric and ab initio Study. J. Phys. Chem. A 2001, 105, 8352-8360.

46. Tureček, F. Modeling Nucleobase Radicals in the Mass Spectrometer. J. Mass Spectrom. 1998, 33, 779-795.

47. Tureček, F.; Wolken, J. K. Dissociation Energies and Kinetics of Aminopyrimidinium Radicals by $\mathrm{Ab}$ Initio and Density Functional Theory. J. Phys. Chem. A 1999, 103, 1905-1912.

48. Belyayev, M. A.; Cournoyer, J. J.; Lin, C.; O'Connor, P. B. The Effect of Radical Trap Moieties on Electron Capture Dissociation Spectra of Substance P. J. Am. Soc. Mass Spectrom., 2006, 17, 1428-1436.

49. NIST Standard Reference Database Number 69, June 2005 Release, http://webbook.nist.gov/chemistry.

50. Tureček, F.; Chen, X. Lysine, Histidine, and Arginine Residues as H-Atom Donors in ECD and ETD. Proceedings of the 54th ASMS Conference on Mass Spectrometry and Allied Topics; Seattle, WA, May, 2006; ThOE pm-03:10.

51. Seymour, J. L.; Tureček, F. Structure, Energetics, and Reactivity of Ternary Complexes of Amino Acids with Cu(II) and 2,2'-Bipyridine by Density Functional Theory. A Combination of Radical-Induced and Spin-Remote Fragmentations. J. Mass Spectrom. 2002, 37, 533-540. 